\title{
Proceeding
}

Supplementary Issue: Rio 2016 Olympic Games First Anniversary Special Edition. Olympic Studies Forum, 4-5 August 2017. Santa Úrsula University. Rio de Janeiro, Brazil

\section{Brazilian identity in transition: The look of the foreign media upon the opening ceremony of the Olympic Games Rio 2016}

\author{
NELSON TODT $\triangle$, PAULA PUHL, ALESSANDRA SCARTON, MICHELLE GUIRAMAND \\ Grupo de Pesquisa em Estudos Olímpicos (GPEO) of Pontifícia Universidade Católica do Rio Grande do Sul \\ (PUCRS), Porto Alegre, Brazil
}

\begin{abstract}
The article aims at an investigation of the forms of narration of Brazil's international image through the Olympic Games Rio 2016. The objective is to extend the knowledge and understanding of narratives upon Brazil and its identity elements which were built abroad in the context of the Olympic Games Rio 2016. Texts from published international newspapers are analyzed as result of the Opening Ceremony. The selection criterion of the periodicals was defined from the participating countries whose official languages were Portuguese, Spanish and or English. The study characterizes itself as a qualitative research, based on bibliographic and documental sources. The analysis showed new identity representations about Brazil, pointing to the presence of new elements, from the reports published by foreign media. Key words: NATIONAL IDENTITY, MEGAEVENTS, RIO 2016 OLYMPIC GAMES, INTERNATIONAL MEDIA.
\end{abstract}

\section{Cite this article as:}

Todt, N., Puhl, P., Scarton, A. \& Guiramand, M. (2018). Brazilian identity in transition: The look of the foreign media upon the opening ceremony of the Olympic Games Rio 2016. Journal of Human Sport and Exercise, 13(1proc), S3-S16. doi:https://doi.org/10.14198/jhse.2018.13.Proc1.02

Corresponding author. Pontifícia Universidade Católica do Rio Grande do Sul, Faculdade de Educação Física e Ciências do Desporto. Avenida Ipiranga, 6681 - Prédio 81. Jardim Botânico. 90619900 - Porto Alegre, RS - Brasil. http://orcid.org/00000002-5179-781X

E-mail: nelson.todt@pucrs.br

Supplementary Issue: Rio 2016 Olympic Games First Anniversary Special Edition. Olympic Studies Forum, 4-5 August 2017. Santa Úrsula University. Rio de Janeiro, Brazil.

JOURNAL OF HUMAN SPORT \& EXERCISE ISSN 1988-5202

(c) Faculty of Education. University of Alicante

doi:10.14198/jhse.2018.13.Proc1.02 


\title{
Identidade brasileira em transição: 0 olhar da mídia estrangeira sobre a cerimônia de abertura dos Jogos Olímpicos Rio 2016
}

\begin{abstract}
RESUMO
O artigo tem como objetivo uma investigação sobre as formas de narração da imagem internacional do Brasil através dos Jogos Olímpicos do Rio 2016. O objetivo é ampliar o conhecimento e a compreensão sobre narrativas sobre o Brasil e seus elementos identitários construídos no exterior no contexto dos Jogos Olímpicos do Rio 2016. São analisados os textos de jornais internacionais publicados como decorrência da Cerimônias de Abertura. $O$ critério de escolha dos periódicos foi definido a partir dos países participantes, que tivessem como idioma português, espanhol ou inglês. $O$ estudo caracteriza-se como uma pesquisa qualitativa, baseada em fontes bibliográficas e documentais. A análise mostrou novas representações identitárias sobre o Brasil, apontando para a presença de novos elementos, a partir das reportagens divulgadas pela mídia estrangeira. Palavras-chave: IDENTIDADE NACIONAL, EVENTOS MEGA, JOGOS OLÍMPICOS RIO 2016, MÍDIA INTERNACIONAL.
\end{abstract}




\section{MEGA EVENTS CONTEXTUALIZATION AND BACKGROUND STUDY}

The present study is the result of an interdisciplinary work carried out by the areas of Physical Education and Social Communication, held at Pontifical Catholic University of Rio Grande do Sul, Brazil, and it seeks to strengthen and disseminate the research developed by the Research Group on Olympic Studies (GPEO)1. Among the lines of investigations is that of the memory and of social representations, having as objects of study the repercussions of the athletes, sports, ceremonies and Olympic Games at different times².

The object of this study starts from the Opening Ceremony of the Olympic Games Rio 2016, held in Rio de Janeiro on the 5th of August at the Maracanã Stadium. The idea of the show was to tell the story of the formation of the Brazilian people and their culture, stressing the importance of caring for the environment. The show created by Andrucha Waddington, Daniela Thomas, and Fernando Meirelles showed a transformation process of Brazil.

The event showed a badly treated country that before 2016 had gone through inflation control, incorporated large portions of its population into the consumer market, had experienced a period of more accelerated and organized economic growth, hosted in less than ten years (some of the largest international sporting events on the planet , i.e. the soccer World Cup in 2014) but , this very country in 2016 was going through changes in the Presidency of the Republic and was also witnessing several political scandals that had surfaced with the investigations of the Operation Car Wash (Operação Lava Jato) ${ }^{3}$.

These events and the consequent dissatisfaction of the population with their rulers had already been reported on the front pages of national and international newspapers from the day of the Confederations Cup (a test event for the Soccer World Cup) in 2013, which showed the deterioration of the national political situation.

However, the construction of a social identity is made of positives and negatives before a series of issues 4 and presents itself as a means to position individuals in the world, through the knowledge that they acquire in relation to the existence of a collective person to whom they belong and identify with (Oliveira, 2006). Although it is subject to multiple interpretations, authors such as Almeida (2007) and Gomes Barbosa \& Drummond (2001) state that the Brazilian cultural identity defines itself structurally through the ambivalence and conciliation between the traditional (the cordial one, the people and the nation) and the modern (the individual, the State and the law).

The sporting events, as globalized phenomena, yield specific senses in different places in relation to what they evoke in a given community, establishing a dialectics between local and universal meanings (Moragás, Rivenburgh \& Larson, 1995). However, as DaMatta (2006) advises, when these visions are taken isolatedly, they assume that the sport has a corresponding sense, expressing a common set of social dramas.

\footnotetext{
1 Description of the Group available at: http://plsql1.cnpq.br/buscaoperacional/detalhegrupo.jsp?grupo=0006409LEOV5GQ. Accessed on 04 th $N$ November 2016.

2 The Group has already produced articles that analyzed the identity representations about the opening ceremony of the 2014 FIFA World Cup, one of the articles can be found at: http://revistaalceu.com.pucrio.br/cgi/cgilua.exe/sys/start.htm?infoid=569\&sid=44. Accessed on 13 October 2017.

${ }^{3}$ Operation Car Wash (Operação Lava Jato) is a set of ongoing investigations by the Federal Police of Brazil, which carried out more than a thousand warrants for search and seizure, temporary arrest, preventive detention and coercive conduct, in order to investigate a money laundering scheme which involved billions of "brazilian reais" in bribery. The operation started on 17 March 2014 and has 45 operational phases. The Federal Police considers it as the largest corruption investigation in the country's history. Information available at: https://en.wikipedia.org/wiki/Opera\%C3\%A30_Lava_Jato. Accessed on 18 October 2017. ${ }^{4}$ For example: family, power, relationship with money, relationship with others, eating habits, among many other things.
} 
Consequently, what happens in the society of the subject-observer is designed as a trace, disposition or tendency of the all human species. In this perspective, the scene of major international sporting events provides a proper context for researches of this genre, once the flow of images and information enables the thinking of a space that articulates the universal and the local, according to different supports of meaning.

The sports ceremonies, in special the Olympic ones, are among the best known and influential ritualization forms of modernity values (DaCosta, 2000; Garcia, 2011 \& Klausen, 1995). Victor Turner understands 'ritual' as "a formal behavior prescribed for occasions which are not devoted to the technological routine, having as reference the belief in beings or mystical powers" (2005, p. 49). Nevertheless, if we follow Peirano's suggestion (2000, p. 2), we may treat the importance attributed to "the belief in beings or mystical powers" as relative, in order to concentrate on the analysis of events that, keeping the acknowledgment which is given to them socially as special phenomena, differ from classic rituals with respect to the elements of probabilistic character these events enjoy". This way, the ritual leaves the plan that is exclusively religious to allow analyses that grant a privilege to its evaluating and identitarian dimensions.

In this context, while the Olympic Games gather universalist rites (the opening and closing ceremonies) and civic nationalist rites (the awarding ceremonies with the right to national anthem and flags), the narrative resulting from the ceremonies serves not only as a national identity affirmation, but also as advanced national publicity and an opportunity to promote tourism, international corporate investments, trade and political ideologies.

This statement, however, must be considered in a context in which the sporting events are, to some extent, a construction made by the media, mainly the ceremonies, which are organized as highly professional shows (Moragás, Rivenburgh \& Larson, 1995).

The arguments of Hall (2003), constructed from the studies about mass communication, seem to provide us with the necessary support to understand how the media builds a determined understanding of reality. Hall has criticized the communicative model in terms of a linear circuit, that is, "sender/ message/ receiver". The author seeks to think the process "in terms of a structure which is produced and supported by the articulation of distinctive moments, but linked - production, circulation, distribution/ consumption, reproduction" (Hall, 2003 , p. 387). To bring the circuit to an end, the codes used by the sender - which here are restrict to print/online media - must be decodified by the readers. "If no "meaning" is taken, there can be no "consumption". If the meaning is not articulated in practice, it has no effect" (Hall, 2003, p. 388).

From these theoretical references, this article has as general goal to expand the knowledge and understanding about the narratives concerning Brazil and its identity elements, which were built by the foreign look of the media in the context of the Olympic Games, and as specific objectives, it aims to identify, describe and analyze narratives related to Brazilian identity, through news and articles published by the international press related to the Opening Ceremony of the Olympic Games Rio 2016.

\section{METHODS AND RESEARCH DESIGN}

This is a quantitative research in terms of data collection and with a qualitative analysis of the data. It has an international character, following the tradition of researches performed by the Center of Olympic Studies in the Autonomous University of Barcelona. The research design used data collected from texts in international newspapers published as a result of the Opening Ceremony of the Olympic Games Rio 2016. 
The methodological alignment adopted for data mapping, description and analysis follows the content analysis (CA) technique proposed by Bardin (2002), defined as a group of communication analysis techniques that aim to obtain markers that allow inference into knowledges related to the conditions of production/reception of these messages. In its original conception, the author structured the content analysis method in four stages: organization of the analysis; coding; categorizing; and inference.

In that sense, in the first stage of CA, organization of the analysis, online newspaper's stories were chosen among the 205 countries participating in the competition ${ }^{5}$, which the language was either Portuguese, Spanish or English. In order to identify the most read newspapers in each country, we have used the online newspaper ranking, using as reference the Net Papers ${ }^{6}$ repository. From that sample, two newspapers from each country were chosen.

In the second phase of $\mathrm{CA}$, the coding, we defined the range for the selection of news stories using the publication date of the stories related to the opening ceremony, between August 04 and 06, 2016. This range was chosen due to the time zones of each country and the time for the publication of the newspapers.

Fifty-eight stories were found about the opening ceremony. A data sheet was created to code the news stories in detail and better organize the material. The sheet had the following topics: country name, newspaper name, story title, URL of the story, presence of pictures, and the description. It was also taken into account if the story was signed by a journalist or agency, and if the picture had a signature. Following that, the data sheet had a field for comments and also a field to separate parts of the text and highlight the stories that were opinion or not. An example of the data sheet is shown on Figure 1 below.

\footnotetext{
${ }^{5}$ According to the Brazilian Olympic Committee, Rio 2016 had 205 countries, 41 modalities, 306 events and 11.544 athletes. Information available at: https://www.cob.org.br/en/time-brasil/brasil-nos-jogos/rio-2016. Accessed on 12 October 2017.

${ }^{6}$ The Net Papers provides 7.659 links to online newspapers in 191 countries, as well as a specific link to the most read newspapers online, separated by country. Available at: http://www.netpapers.com/jornais-more-lidos. Accessed on 12 October 2017.
} 


\begin{tabular}{|c|c|c|c|c|}
\hline \multicolumn{5}{|c|}{ FICHA TECNICA } \\
\hline \multicolumn{5}{|c|}{ Bermudas } \\
\hline \multicolumn{2}{|l|}{ Jornal } & \multicolumn{3}{|c|}{ The Roval Gazetre } \\
\hline \multicolumn{2}{|l|}{ Titulo } & \multicolumn{3}{|c|}{ Boisterous ceremony silences the doubters } \\
\hline \multicolumn{2}{|l|}{ URL } & \multicolumn{3}{|c|}{ goo.gl/CXHrNe } \\
\hline \multicolumn{2}{|l|}{ Foto } & $\operatorname{Sim}(x)$ & Quantas (1) & Não () \\
\hline \multicolumn{2}{|c|}{ Descrição da foto: } & \multicolumn{3}{|c|}{ Momento da cerimonia de Abertura } \\
\hline \multicolumn{2}{|c|}{ Assinatura } & $\operatorname{Sim}(x)$ & $\begin{array}{l}\text { Quem? Stephen } \\
\text { Wright }\end{array}$ & Não () \\
\hline Comentários: & \multicolumn{4}{|c|}{\begin{tabular}{|l|l|} 
Constam $(x)$ & Não constam () \\
\end{tabular}} \\
\hline \multirow{2}{*}{ 1. OPINATIVO } & \multicolumn{4}{|c|}{$\begin{array}{l}\text { Perched at the peak of Mount Corcovado, christ the Redeemer peered on approvingly from high } \\
\text { above the Maracana stadium during last night's olympic Games opening ceremony. }\end{array}$} \\
\hline & \multicolumn{4}{|c|}{$\begin{array}{l}\text { Empoleirado no pico do Monte Corcovado, Cristo Redentor olhou com aprovação de alto sobre o } \\
\text { Estádio Maracanã durante a cerimônia de abertura dos Jogos Olimpicos de ontem a noite. }\end{array}$} \\
\hline \multirow{2}{*}{ 2. OPINATIVO } & \multicolumn{4}{|c|}{$\begin{array}{l}\text { The fluorescent glow emanating from the symbol of Christianity, fitting ily in Brazil's yellow and green } \\
\text { colours, seemed to dissipate the gloom that has enveloped the build-up to these Games. }\end{array}$} \\
\hline & \multicolumn{4}{|c|}{$\begin{array}{l}\text { O briho fuorescente que emanava do simbolo do cristianismo, apropriadamente nas cores amare as } \\
\text { everdes do Brasil, parecia dissipar a tristeza que envolveu a construşà desses Jogos }\end{array}$} \\
\hline \multirow{2}{*}{ 3. OPINATIVO } & \multicolumn{4}{|c|}{$\begin{array}{l}\text { One thing is for certain, though: if ever there was a Games in need of a boost in self-esteem, it was } \\
\text { this one. }\end{array}$} \\
\hline & \multicolumn{4}{|c|}{$\begin{array}{l}\text { Uma coisa é certa, no entanto: se alguma vez houve um Jogos que precisam de um impulso na } \\
\text { auto-estima, foi este. }\end{array}$} \\
\hline
\end{tabular}

Source: Grupo de Pesquisa em Estudos Olímpicos da PUCRS (2017)

Figure 1. Data sheet for data collection

However, in order to focus on news stories that have an opinion and not merely a description of those moments, we have focused solely on opinion texts. According to Beltrão (1980), the opinion type comment is that which passes judgment or elaborates considerations about the theme, agreeing, disagreeing, or emitting a new point of view. In that sense, our sample was reduced as shown in Table 1:

Table 1. Sample description

\begin{tabular}{|l|c|c|}
\hline & Matérias Opinativas & Número de Países \\
\hline Cerimônia de Abertura Rio 2016 & 40 & 31 \\
\hline
\end{tabular}

Source: Grupo de Pesquisa em Estudos Olímpicos da PUCRS (2017)

After this classification and a detailed reading of the news stories to fill in the spread sheets, categories were defined using the observation of themes that were repeated the most in them. The chosen categories were: ceremony and opening of the Games (Category 1), and artistic expressions (Category 2). A brief summary of the opening ceremony is presented and following it appointments about the analysis of the news stories. 


\section{THE OPENING CEREMONY OF RIO 2016}

The ceremony occurred on August 5th, 2016, at 10 PM, at the Maracanã stadium, in the city of Rio de Janeiro, Brazil. The following information has as a basis the casting of the Olympic Channel7and the published news stories on the news site 8 .

The festivity began with the big screens in the stadium showing scenes of people practicing sports in various parts of the city of Rio de Janeiro, to the sound of the song "Aquele abraço", composed by Gilberto Gil, sung by Luiz Melodia. After that, Paulinho da Viola sang the national anthem accompanied by a string octet while the national flag was hoisted.

In general terms, the ceremony told then the story of Brazil's formation, since the arrival of the first creatures and the creation of the forests, to the arrival of the first indigenous people, of the Portuguese in their caravels and the people from Africa. Some of them with their feet bound and with wooden yokes on the backs of others represented the stain of slavery in Brazil's history.

Dancers represented also the arrival of the Arabic and Japanese, at the end of the $19^{\text {th }}$ and beginning of the $20^{\text {th }}$ century. There was also a homage to Santos Dumont in this part of the event, where dancers used paper cubes that transformed into a replica of the 14-Bis, which took flight at the Maracanã and flew over the city of Rio de Janeiro, displaying some of its top tourist places.

One of the most acclaimed moments by the people in the stadium was Gisele Bündchen's walkway performance, to the sound of "Garota de Ipanema", Tom Jobim's song, sung by the musician's son, Paulo Jobim. From that point on, Brazilian music was the center of attentions. From bossa nova, to samba and funk, with performances by Elza Soares with the song "Canto de Ossanha", Marcelo D2 and Paulinho da Viola with a medley of "Deixa a vida me levar." Capoeira appeared in a presentation by a 12-year-old girl, while rappers MC Sofia and Karol Conka also did their performance, representing the affirmation of women's power in Brazilian society.

The Brazilian folk festivities were represented by a huge show of maracatus where spaces were disputed when the actress Regina Casé enters the scene and asks for support to diversity. One of the highlights was when Jorge Ben Jor, being publicly acclaimed, entered the stage to sing the song "País Tropical."

The final part of the ceremony had an environmental message. A video spoke of the dangers of global heating with a thermometer showing the increases in temperature around the world due to the actions of mankind, the melting of the polar ice in the last years, and the dangers of rising sea levels.

This part of the show counted with the acting of a boy that wandered down the way and found a lonely plant. In this moment the poem "A flor e a náusea", of Carlos Drummond de Andrade, was declaimed by the Brazilian actress Fernanda Montenegro (in Portuguese) and by the English actress Judi Dench (in English).

\footnotetext{
7 Information available at: https://www.olympicchannel.com/en/playback/viva/viva/viva-documentario-da-cerimonia-de-aberturada-rio-2016/. Accessed on 12 October 2017.

${ }^{8}$ Reports used for the description available at: https://oglobo.globo.com/esportes/cerimonia-de-abertura-da-rio-2016-emocionacom-historia-dos-povos-brasiliros-19864341\#ixzz4lt6XsU00/ and http://g1.globo.com/rio-dejaneiro/olimpiadas/rio2016/noticia/2016/08/pira-da-candelaria-e-acesa-e-encerra-cerimonia-de-abertura-da-olimpiada.html. Accessed on 12 October 2017.
} 
Shortly after, the parades of the delegations began with highlights to the refugee athletes. After that, the Olympic flag was hoisted to the sound of the Olympic anthem (composed in 1896), sung by children from a social project in the city of Niterói, in Rio de Janeiro. The end of the ceremony was a party that transformed into Carnaval with the participation of the twelve samba school bands from Rio.

At the end of the opening ceremony, the last part of the passing of the Olympic flame took place, when Gustavo Kuerten ${ }^{9}$ brought the torch to the stadium, passed it to Hortência Marcari ${ }^{10}$, who finally took it to the ultimate conductor, Vanderlei Cordeiro de Lima ${ }^{11}$ that lit the Olympic Pyre. The pyre gained renown for being in front of the sculpture of the plastic artist Anthony Howe, forming a conjunction that represented the Sun and was one of the most highlighted images during the games. Some of the opening ceremony images are presented on Figure 2:
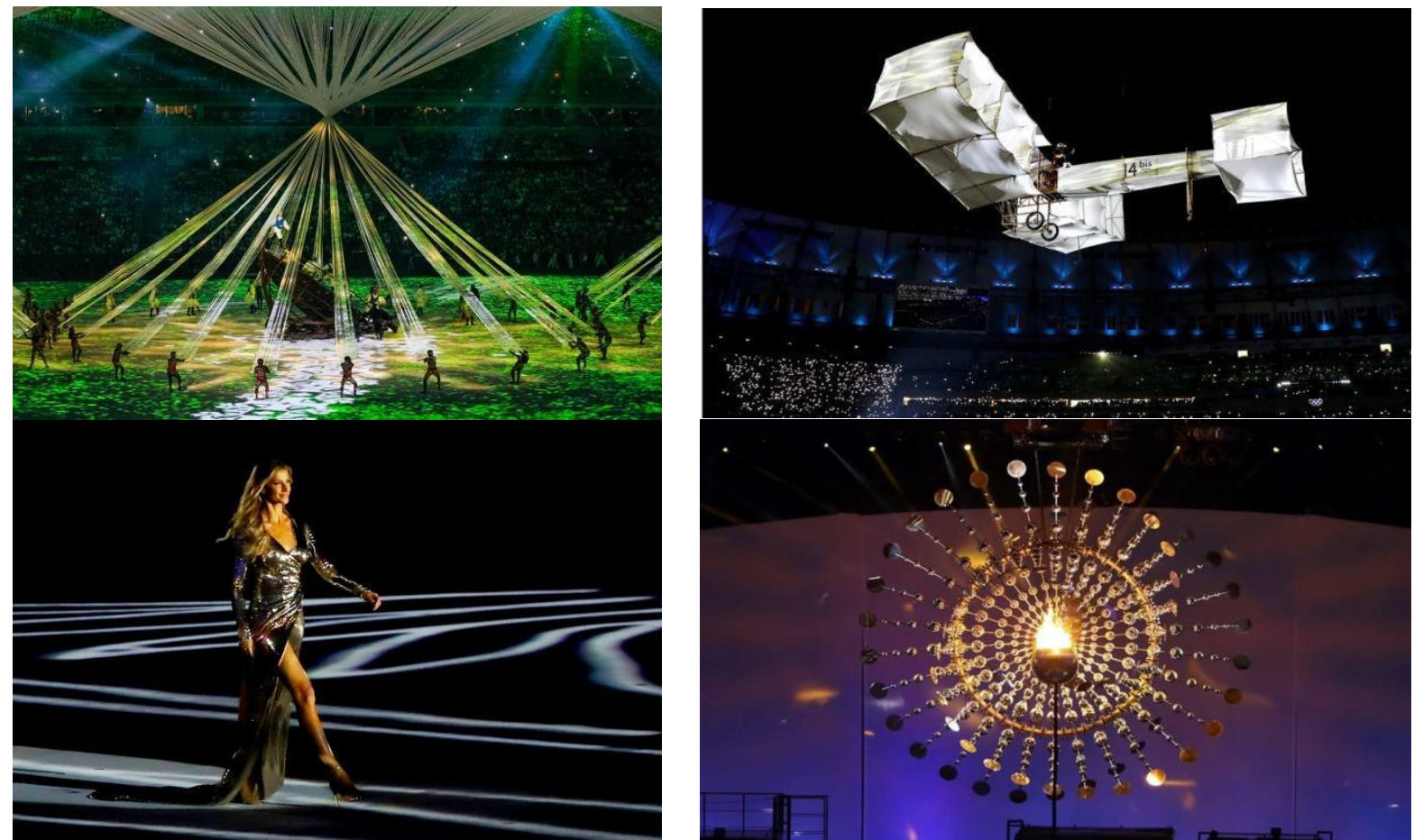

Source: Olympic Channel (2017)

Figure 2. Images of the opening ceremony Rio 2016

As the description and the images of some of the main moments of the ceremony show, a reference to the various ethnicities of Brazil was perceived, the natural beauties were highlighted, as well as the care for the environment in the country. Samba, carnaval, bossa nova and funk divided the stage with poetry and the beauty of the Brazilian women in a colorful opening that counted with a grand structure and many participants.

In Figure 3 it is possible to have a clearer idea of the numbers of the Opening Ceremony through the Infographic made available by the organizers of Rio 2016, with the figures of the opening event:

\footnotetext{
9 Brazilian tennis player at the 2000 and 2004 Olympic Games.

10 Brazilian basketball player at the 1992 and 1996 Olympic Games.

11 Brazilian marathon runner at the 2004 Olympic Games and the only Brazilian to be awarded with the Pierre de Coubertin Medal.
} 


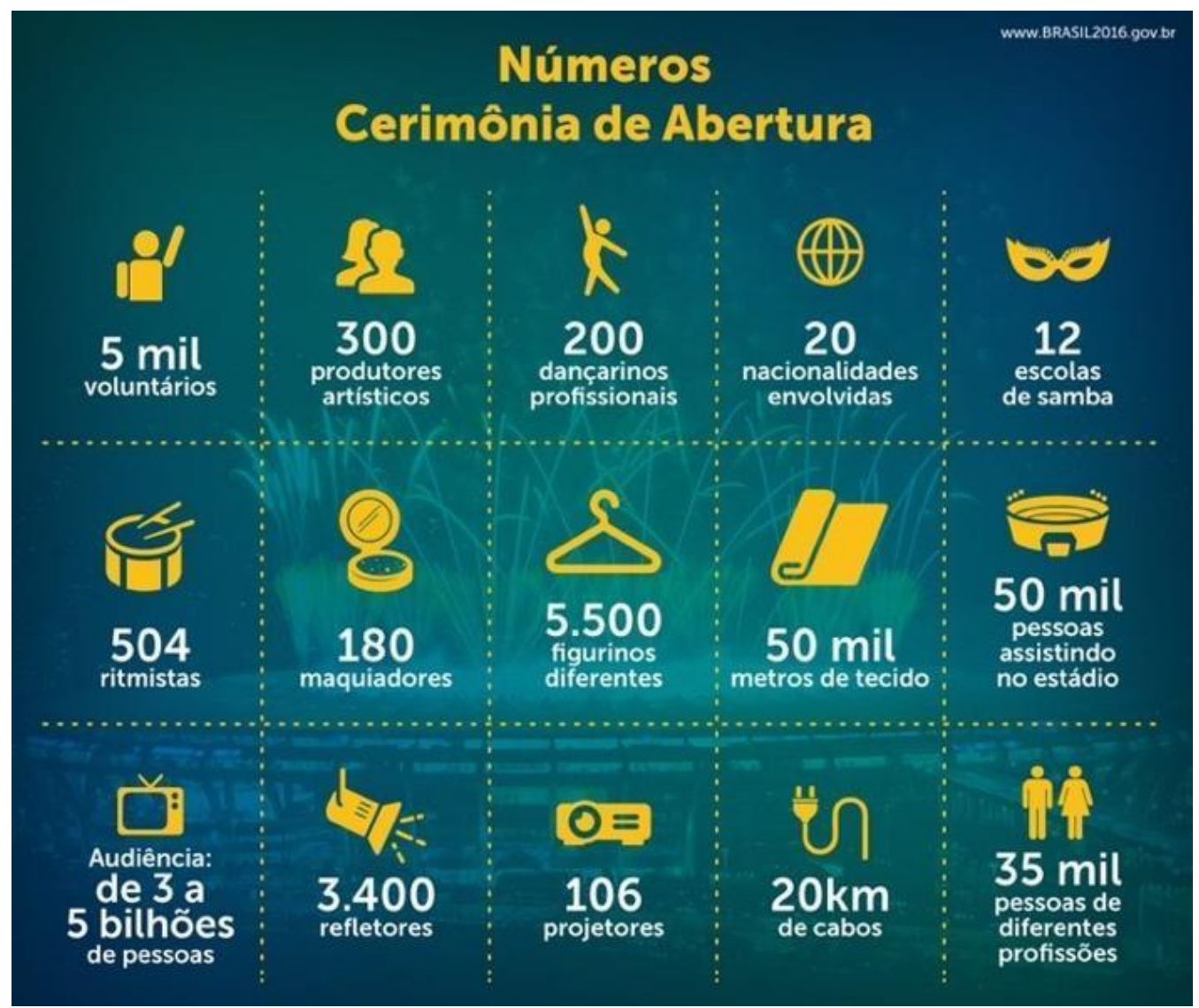

Source: Organization Rio 2016

Figure 3. Numbers of the opening ceremony Rio 2016

\section{THE ANALYSIS OF THE REPRESENTATION OF THE BRAZILIAN IDENTITIES FROM THE FOREIGN LOOK}

As already stated by the literature review on the topic of identities and sporting mega events, the publicization of the media has a key role in the dissemination and legitimation of identities. As Hogan (2003) states, the narrative resulting from the ceremonies serves not only as an assertion of national identity, but also as advanced national advertising and a chance to promote tourism, international business investments, trade and political ideologies. The analysis will be guided by the reflection upon how the presence of the Olympic Games in Brazil contributed and/or reinforced/modified the understanding of Brazilian identities, since the country was present on the agenda of both national and international media.

From this point of view, the analysis will highlight points that referred to information about elements that were part of the opening of the games as the artistic expressions (Category 1 ) and the citation of the social and political events in the country (Category 2), exemplified with excerpts from collected news reports. With the intention to contribute to the understanding of the analysis, the titles of the news reports are presented in their original languages and the link to the full text will be made available in a footnote, but the comments made on the full text are already translated and are highlighted as indented quotes or italicized text when they appear in the body of the text. As mentioned before, a total of 40 news reports with opinionated content were collected in Portuguese, English and Spanish. Due to the large number of reports, the contents will be 
arranged considering the themes that stood out in a set of news reports which hold some relationship preponderant aspects in the understanding of identity aspects.

The concept of identity is related directly with the idea of the difference. According to Silva (2009) identity is what it is, an autonomous fact. The identity has reference to itself and is self-sufficient. The difference, on its turn, is what the other is, that is, it is self-referential. These concepts have dependency relationship, that is, many times we stated what it is from the assessment of what one does not want to be. In this sense, it is important to clarify that both the identity and the difference are part of the cultural and social relations, and frequently, they should not be understood outside of the systems of signification in which they acquire meaning. That is why it is important to understand to what extent the foreign look beholds the Brazilian culture and the society, in order to compare the similarities and the differences to what has already been legitimated with Brazilian identity.

From this perspective, it has been observed that some foreign online newspapers articles presented not only positive commentaries, the well-known comments about the Brazilian nation, such as citations referring to happiness, nature and the country's beauty, but also negative aspects about its social and political conditions, as well as references to the environment, a highly discussed issue before and during the games in the national media ${ }^{12}$.

An example of it was an approach made by the newspaper La Nación, in Costa Rica's edition, that published the news report: Ritmo, color y belleza en inauguración de Juegos de Rio ${ }^{13}$, in which the country's beauty and cultural wealth were highlighted, yet it has also emphasized the social inequalities, as shown in the citation below:

There was music, history and beauty, as one would expect from a country like Brazil. And among an amazing swirl of colors, the opening ceremony of the Olympic Games in Rio de Janeiro left a message of brotherhood and environmental awareness in a nation that needs more than ever [...] The environment. The night show toured the broad spectrum of Brazil's history, a country so rich in natural resources and history, yet, full of inequality and poverty.

It is perceived a positive parallel that refers to the country's history and its aspects, but it also reminds us of the country's poverty situation that got worse in 2016. In this very way, the IOL newspaper of South Africa has also highlighted the dissonance between the Brazilian people's positive attitude before the social problems in the news report: Games overshadow Rio's problems ${ }^{14}$ in the citation, "The smile is the approach that Brazilians have towards life. Brazil is not a great nation. They say in this ceremony, we are who we are, with many social problems, many crises in the political system". This idea of hope and sympathy meets what DaMatta (1994) conceptualize as "jeitinho brasileiro" ( Brazilian way of doing), a strategy used to deal with what is possible or not in the social reality; it is a sympathetic way that relates the personal and the impersonal and helps reconcile the interests of all parts involved.

The Expresso das Ilhas, a Cape Verde's newspaper, in the news report Começou a festaOlímpica (The Olympic party started) ${ }^{15}$,besides drawing attention to the spectacle that was presented, it cited the

\footnotetext{
${ }^{12}$ As an example the Folha de São Paulo report entitled: Olympic Promises. Available at: http://temas.folha.uol.com.br/um-mespara-a-olimpiada/meio-ambiente/rio-descumpre-todas-as-ambientais-para-a-imimada.shtml. Accessed on 13 October 2017.

${ }^{13}$ Report available at: $\mathrm{http}: / / \mathrm{goo} . \mathrm{gl} / \mathrm{cZ68Qd}$. Accessed on 13 October 2017.

14 Report available at: http://goo.gl/NN1GC3. Accessed on 13 October 2017.

15 Report available at: http://goo.gl/CMf4vl. Accessed on 13 October 2017.
} 
relationship of Brazilians with the current president, an interim president at that time, when it stated that: "Michel Temer, who has spoken for just few seconds in the end of the show, to declare that the Olympic Games were open could not avoid getting the expected boo that the event organization tried to muffle without much success".

The Townsville Bulletin, from Australia, in its news report: Rio Olympics opening ceremony from Maracana Stadium $^{16}$, also emphasized the lack of empathy from the audience with the president, as we can verify in the following citation: "[...] mockery and jeers greeted the interim president Michel Temer, before he declared South America's first Olympic Games open".

With these lines we realize how the ceremonies reflect something beyond what is presented, and they can serve as a tool to understand something that is not intentionally shown, nor scheduled by the event organizers, as the rejection of the President. And as the media always seeks something that is not in sight, some newspapers have highlighted this positioning of Brazilians.

On the other hand, the Argentinian newspaper Olé, in its news report: Largaron los Juegos ${ }^{17}$, gave more emphasis to the joyful atmosphere that was enabled by the opening ceremony and the presence of the international model Gisele Bündchen, as we can observe in the following statement:

Honoring the name of the host city, the joy was the axis throughout the ceremony, with a lot of movement and lights that extended from the ground to the sky. Various choreographies, a plane flew to the Christ the Redeemer Statue, the appearance of the model Gisele Bündchen as the girl from Ipanema and hundreds of fireworks thrilled everyone, before more than 200 delegations from various countries started parading.

The Straits Times from Singapore, in its news report: Olympics - Rio's glittering opening launches 2016 Games $^{18}$ also highlighted the supermodel's starring role. The news report has also commented about political issues.

As the clock struck the beginning of the ceremony, thousands of demonstrators took to the streets to vent their fury at Brazil's rulers and the multi-billion-dollar cost of the Games. The supermodel Gisele Bündchen strutted into the arena to the iconic "Girl From Ipanema" before Greece, home of the ancient Olympics, took its traditional place at the head of the athletes' parade.

Gisele's appearance at the event has certainly collaborated to the legitimation of Brazilian women's beauty, and it spawned numerous comments and images in the international media, however, even with the event organizers' attempt to establish an agenda for the media, the biggest number of news reports still highlighted the country's problems, as one can see in The New York Times publication, entitled A Gilded Olympics Begin With the Opening Ceremony in Gritty Rio ${ }^{19}$, which brought attention to the problem regarding the favelas' (slums) growth hanging over Rio's beaches, once the image of these places served as scenography for the ceremony, when it states: "In a country of great economic inequality, the opening ceremony celebrated the culture of the favelas, the slums that hang down precipitously on the famous beaches of Rio de Janeiro [...]".

\footnotetext{
${ }^{16}$ Report available at: http://goo.gl/6nUOXZ. Access on 13 October 2017

${ }_{17}$ Report available at: http://goo.gl//ntWR2. Accessed on 13 October 2017.

${ }^{18}$ Report available at: https://goo.gl//LFJYb. Accessed on 13 October 2017.

${ }_{19}$ Report available at: http:// goo.gl/105Rps. Accessed on 13 October 2017.
} 
The New York Times also quoted the joy offered by the ceremony of the first Games in South America, though it emphasized that this joy "contrasted with months of turmoil and chaos, not only in the organization of the Olympic Games, but in the whole Brazil, which is suffering the worst economic recession in decades and a deep political crisis. "Something curious in this story, written by the reporter Simon Romero, is the adding of a part of the event in which the word "gambiarra" was mentioned, which means quick-fix, a form of problem-solving without having all the necessary tools to do so. Bringing up the word "gambiarra" in a solemn moment, makes it official the already known "jeitinho brasileiro" (the Brazilian way of doing) conceptualized by DaMatta. As quoted by Romero, in his understanding of the concept: "the organizers of the ceremony even chose a word in Portuguese, gambiarra, to describe their own efforts to put on a show amidst Rio's pared-down Olympic ambitions Rio". That is to say, to admit this way of solving important issues, using the Brazilian way of doing (o jeitinho), is to admit "gambiarra" as the country's identity brand in international network.

Somehow, the other reports of the data set also reinforce such Brazilian practice of overcoming economic barriers and acting with joy and sentiment in solving problems, as stated by the news report of Angola's newspaper - Ceromónia do Maracanã apresenta um Brasil rea/20 - which brought a more positive approach in the following excerpt, comparing it with the opening ceremonies of the Games in Beijing and London:

The Brazilian opening party of the biggest sporting event in the world touched deeply the hearts of the Olympic family, with strong messages about social inclusion, celebration of differences, preservation of the environment and, above all, bringing to the Maracanã venue the best of its most obscure reality, the favelas (slums).

The news report also highlighted that: "The opening of the Olympic Games showed a nation that, although finding itself steeped in a sea of troubles, can be very strong, when united".

The idea of a united nation and the cultural diversity appreciation was also present in the news report of the Diario Libre, from the Dominican Republic, De la samba al funk: la favela hacebailar al Maracaná21, which stated the importance of the events chosen for the opening ceremony: "Samba, ritmos passinho e funk, danças nascidas nas favelas [...] virou a abertura dos Jogos Olímpicos em uma festa com o poder esmagador da cultura negra". The same emphasis was also present in the article: Se inauguro Río 201622, published by the newspaper Ovación from Uruguay:

Brazil celebrated its exuberant natural resources and the creative energy of its population to the rhythm of samba, bossa nova and funk at the opening ceremony in which it welcomed the world to the Olympic Games of Rio de Janeiro.

The presence of the black culture expressed by the funk, the samba and Carnival in unison with bossa nova, somehow showed the importance of the Brazilian cultural diversity, which enables an identity to transit between what the country boasts as positive aspects and negative aspects, regarding social inequalities and political actions.

The news reports, even pointing out to different points of view, were able to understand the complexity of the Brazilian nation. The opening ceremony emphasized the popular culture, the importance of the country's

${ }^{20}$ Report available at: $h$ ttp:// goo.gl/Ni9G4A. Accessed on 13 October 2017.

${ }^{21}$ Report available at http://goo.gl/wiOxwd. Accessed on 13 October 2017.

22 Report available at: http://goo.gl/5Ygkm6. Accessed on 13 October 2017. 
colonization history reflected on the population's cultural practices, becoming part of the Brazilian tradition. In this way, we agree with Ortiz (1994), who believes the national is that which belongs to the people, formed by a collective popular memory that collaborates to the legitimation of a national memory, legitimized by the State, but in this case the legitimation was also made by the mediatic show, which crossed frontiers and allowed numerous interpretations of what it means to be Brazilian.

\section{FINAL CONSIDERATIONS}

This article has shown an illustrative point of view of qualitative character. It is important to highlight that it is not only the outsiders point of view that defines the identity of a nation. We comprehend that distancing may generate shallow interpretations, as well as it is known that the media are responsible for the outlining of the facts. However, understanding how other people observe a specific culture may become an instrument of evaluation that can be used to review social, cultural and political practices, and may bring to light and invoke reflections about how a country is seen, something that does not occur when you are inside the system.

Possibly, this mixture of elements that are part of the Brazilian identities may suffer alterations in time or may need to be legitimized in order to account for the social reality of the country, once that the nation observes daily the news about the several investigative processes around politicians. The most recent case, in connection with the Olympic Games of 2016, was the arrest of Rio de Janeiro's governor in 2016, during the games candidacy, Sérgio Cabral, and in 2017 it was published in national and international media the arrest of Carlos Nuzman, president of the Brazilian Olympic Committee and the Games Organization Committee, charged with vote-buying among members of the International Olympic Committee, in order to host the games of $2016^{23}$. News that are not positive for a nation that accepted and did pits best to receive the Olympic Games of 2016.

Somehow, we believe that the identity represented by the opening ceremony of Rio 2016 , along with the declarations about the external demonstrations highlighted by the international media, contributed to show a country in transition, more transparent to the foreign eyes. The floodlights that generally shined only on the old costumes and traditions, and the natural happiness of the people were overshadowed, at least in part, by the social and political matters. However, it is still possible to notice the focus on Brazil's natural beauties, and the happiness of a people that is still recognized by its hope, that is always making a "gambiarra" (cutting a corner) to survive gracefully in light of their problems - identity characteristics that perhaps have an expiration date when faced by the new challenges of the Brazilian people.

\section{REFERENCES}

Almeida, A. C. (2007). A Cabeça do Brasileiro. Rio de Janeiro: Record.

Bardin, L. (2002). Análise de conteúdo. São Paulo: Edições 70.

DaCosta, L. P. (2000). Olympic Studies: current intelectual crossroads. Rio de Janeiro: Ed. Gama Filho.

DaMatta, R. (1994). O Que Faz o Brasil, Brasil? Rio de Janeiro, Rocco.

DaMatta, R. (2006). A bola corre mais do que os homens. Rio de Janeiro: Rocco.

Garcia, N. (2011). The Olympic Ceremonies at Barcelona'92: The vast smorgasbord of media images. In: Peña, E. F., Cerezuela, B., Benosa, M. G., Kennett, C. \& Moragas, M. (Eds.). Mosaico Olímpico:

${ }^{23}$ Information retrieved from: https://oglobo.globo.com/brasi/lava-jato-apura-fraude-na-olimpiada-do-rio-2016-intima-nuzmanmanda-prender-rei-arthur- 21786205. Accessed on 14 October 2017. 
Investigación multidisplinar y difusion de los estudios olímpicos - CEO-UAB 20 años. Barcelona: CEO-UAB.

Gomes, L. G., Barbosa, L. \& Drummond, J. A. (2001) O Brasil não é para Principiantes: Carnavais, Malandros e Heróis 20 anos depois. Rio de Janeiro: Ed. FGV.

Hall, S. (2005). A identidade cultural na pós-modernidade. Rio de Janeiro: DP\&A.

Klausen, A. M. (1995. p. 1-8). Introduction. In: (Ed.) Olympic Games as Performance and Public Event. New York: Bergham Books.

Moragas, M. (1993). La Cultura mediterránea en los Juegos Olímpicos de Barcelona'92. Barcelona: Centre d'Estudis Olímpics-UAB.

Moragás, M., Rivenburgh, N. \& Larson, J. F. (1995) Television in the Olympics. London: John Libbey.

Oliveira, R. C. (2006). Caminhos da Identidade: Ensaios sobre etnicidade e multiculturalismo. São Paulo: UNESP.

Ortiz, R. (1994). Cultura Brasileira e Identidade Nacional. São Paulo, Brasiliense.

Peirano, M. (2000). A análise Antropológica dos Rituais. (Antropologia. N 270). Universidade de Brasília. Rivenburgh, N. K. (1996). Television and the Construction of Identity. Barcelona and Catalonia as Olympic Host. In: Moragas, M., MacAloon, J. \& Llinés, M. (Ed.). Olympic Ceremonies: Historical Continuity and Cultural Exchange. Lausanne: International Olympic Committee.

\section{@) $\Theta \Theta \Theta$}

This title is licensed under a Creative Commons Attribution-NonCommercial-NoDerivs 3.0 Unported License. 